\title{
Triterpenic Acids from Potentilla parvifolia and Their Protective Effects against Okadaic Acid Induced Neurotoxicity in Differentiated SH-SY5Y Cells
}

\author{
Zhen-zhen Yuan, ${ }^{a, b}$ You-rui Suo, ${ }^{a, c}$ Xue-yan Hao, ${ }^{d}$ Shu-lin Wang, ${ }^{b}$ Gang Li, ${ }^{*, d}$ and \\ Hong-lun Wang*,a,c \\ ${ }^{a}$ State Key Laboratory of Plateau Ecology and Agriculture, Qinghai University; Xining 810016, China: \\ ${ }^{b}$ Agriculture and Animal Husbandry College, Qinghai University; Xining 810016, China: ${ }^{c}$ Key Laboratory of Tibetan \\ Medicine Research, Northwest Institute of Plateau Biology, Chinese Academy of Sciences; Xining 810008, China: and \\ ${ }^{d}$ Center for Mitochondria and Healthy Aging, College of Life Sciences, Yantai University; Yantai 264005, China. \\ Received December 15, 2017; accepted March 23, 2018; advance publication released online April 3, 2018
}

Six triterpenic acids were separated and purified from the ethyl acetate extractive fraction of ethanol extracts of Potentilla parvifolia Fisch. using a variety of chromatographic methods. The neuroprotective effects of these triterpenoids were investigated in the present study, in which the okadaic acid induced neurotoxicity in human neuroblastoma SH-SY5Y cells were used as an Alzheimer's disease cell model in vitro. The cell model was established with all trans-retinoic acid $(5 \mu \mathrm{mol} / \mathrm{L}, 4 \mathrm{~d})$ and okadaic acid $(40 \mathrm{nmol} / \mathrm{L}, 6 \mathrm{~h})$ treatments to induce tau phosphorylation and synaptic atrophy. Subsequently, the neuroprotective effects of these triterpenic acids were evaluated in vitro by this cell model. Results from the Western blot and morphology analysis suggested that compounds 3-6 had the better neuroprotective effects. Furthermore, we tested the level of mitochondrial reactive oxygen species and mitochondrial membrane potential of these compounds in SH-SY5Y cells by flow cytometry technology to investigate the potential neuroprotective mechanism of these compounds. All of the results indicated that maybe the mechanism of compounds 5 and 6 is to protect the cell from mitochondrial oxidative stress injuries. cies

Key words Potentilla parvifolia; triterpenic acid; SH-SY5Y cell; tau phosphorylation; reactive oxygen spe-

Alzheimer's diseasea (AD) is a complex neurodegenerative disease, which happens in elderly people worldwide, characterized by progressive cognitive impairments and severe irreversible behavioral abnormalities. One of the most important hallmark of neuropathological lesions in AD is the intracellular neurofibrillary tangles (NFTs) which are composed of microtubule-associated protein tau protein in an abnormal phosphorylated form, but the mechanism of tau hyperphosphorylation in AD is still unclear. ${ }^{1,2)}$ Human neuroblastoma SH-SY5Y cell lines can be differentiated from a neuroblastlike state into mature human neurons by being treated with a variety of differentiation agents, such as neurotrophic factors retinoic acid or phorbol ester, or staurosporine, or brainderived neurotrophic factor. ${ }^{3,4)}$ Okadaic acid (OA) is a potent inhibitor of serine/threonine (Ser/Thr) phosphatases, it can induce hyperphosphorylation of tau protein in SH-SY5Y cells that are similar to the phenomenon found in $\mathrm{AD}$, therefore, it can be considered as a research model of $\mathrm{AD} .^{1)}$ Moreover, OA-induced neurotoxicity plays a relative crucial role in AD. Thus, the neuroprotection against OA-induced toxicity for preventing and/or treating AD should be studied further. It is well known that mitochondrial dysfunction is an important early event in the development of AD. ${ }^{5)}$ Mitochondria are not only responsible for ATP production, but also are a major source of reactive oxygen species (ROS) and oxidative stress and key contributors to aging and neurodegenerative disorders. Mitochondrial dysfunction and oxidative stress are known to be implicated in AD pathogenesis. ${ }^{6,7)}$

Potentilla parvifolia Fisch. (Rosaceae) is known as a traditional Tibetan and Chinese medicine in China. ${ }^{8,9)}$ It is widely distributed in many provinces of China, such as Heilongjiang, Inner Mongolia, Shanxi, Gansu, Qinghai, Sichuan, Tibet and Xinjiang. ${ }^{8,10,11)}$ The aerial parts of this plant (especially the leaves and flowers) are used for the treatment of skin diseases, mastitis, breast cancer, beriberi and edema. ${ }^{8,12)}$ However, there are few reports on its chemical compositions and the related biological activities. Phytochemical studies on Potentilla revealed that triterpenes, flavonoids and tannins are the main important constituents of these plants. ${ }^{13)}$ It is reported that triterpenes have shown neuroprotective activities. ${ }^{14-16)}$ Herein, we report the isolation of six triterpenic acids (1-6) from $P$. parvifolia (Fig. 1), and investigate their neuroprotective effects in vitro. To the best of our knowledge, all of the six compounds were isolated from $P$. parvifolia for the first time, and it is also the first report on the triterpenes chemical compositions from $P$. parvifolia.

In the present research, the in vitro $\mathrm{AD}$ cell model were established as described in our previous study ${ }^{17)}$ : the human SH-SY5Y neuroblastoma cells were differentiated into mature neurons by treating with $5 \mu \mathrm{mol} / \mathrm{L}$ all trans-retinoic acid (ATRA), then the differentiated SH-SY5Y cells were treated with $40 \mathrm{nmol} / \mathrm{L} \mathrm{OA}$ for $6 \mathrm{~h}$ to simulate the phosphorylation of tau, and this can induce changes similar to those occurring in vivo in AD. Herein, we evaluated the neuroprotective effects of the six triterpenic acids from $P$. parvifolia against OA induced tau phosphorylation in SH-SY5Y cells in vitro by the above cell model. Furthermore, we evaluated the potential neuroprotective mechanism of these compounds in SH-SY5Y cells which were mainly related to the mitochondria. This is the first investigation on the screening of neuroprotective ac- 


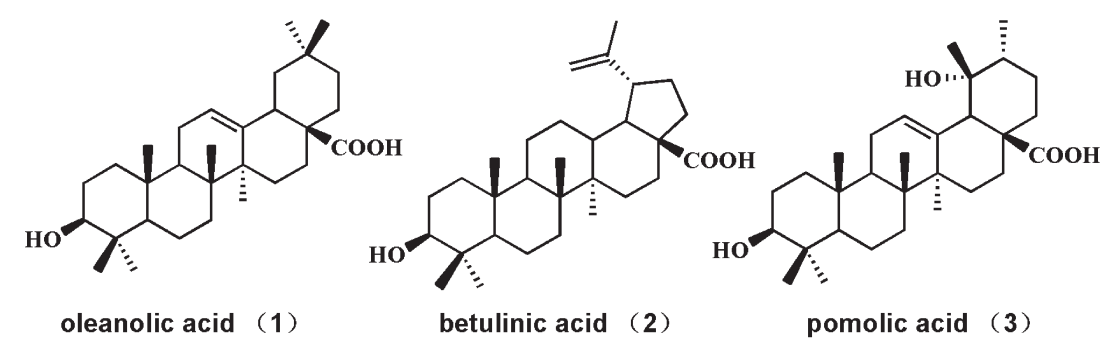

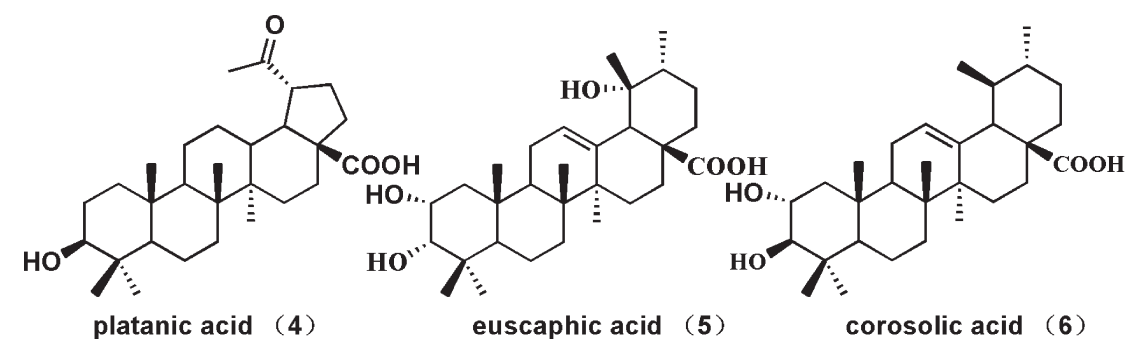

Fig. 1. Chemical Structures of Oleanolic Acid (1), Betulinic Acid (2), Pomolic Acid (3), Platanic Acid (4), Euscaphic Acid (5) and Corosolic Acid (6)

tivity of the triterpenes components in P. parvifolia.

\section{MATERIALS AND METHODS}

Plant Material The aerial parts of $P$. parvifolia were collected from Haibei Prefecture of Qinghai, China, in August 2014. Affirmative identification of the plant was provided by Dr. Faqi Zhang (Northwest Institute of Plateau Biology, Chinese Academy of Sciences, Xining, China), and the plant was authenticated using the voucher specimen in the QinghaiTibetan Plateau Museum of Biology (Xining, China) (reference No. 252558).

Isolation of the Six Triterpenic Acids Details of the extraction have previously been reported. ${ }^{17)}$ Briefly, dried powdered aerial parts of $P$. parvifolia $(6.5 \mathrm{~kg})$ were extracted with $70 \%$ ethanol and partitioned with petroleum ether, EtOAc and $n-\mathrm{BuOH}$, respectively, yielding a EtOAc extract $(103 \mathrm{~g})$ and a $\mathrm{BuOH}$ extract $(97 \mathrm{~g})$ after removal of the solvent by evaporation. The EtOAc extract was fractionated via silica gel (100-200 mesh) column chromatography and based on the gel TLC, the resulting elutes were combined into 9 fractions (Sh1-Sh9). Fraction Sh2 (9.7g) was passed through a silica gel (160-200 mesh) column, eluting with a gradient of petroleum ether-ethyl acetate $(10: 1,8: 1,6: 1,5: 1,3: 1,2: 1,1: 1)$, to give 7 fractions (Sh2-1-Sh2-7). Fraction Sh2-2 was separated by Sephadex LH-20 gel, eluting with $\mathrm{CHCl}_{3}-\mathrm{CH}_{3} \mathrm{OH}(2: 1)$, yielding 5 fractions (Sh2-2A-Sh2-2E). Fraction Sh2-2B was purified by a silica gel (200-300 mesh) column, eluting with a gradient of $\mathrm{CHCl}_{3}-\mathrm{CH}_{3} \mathrm{OH}(100: 1,80: 1,50: 1,40: 1,30: 1$, $20: 1,10: 1,5: 1,2: 1)$, yielding compounds 1 (150 mg, 98.1\%) and $2(350 \mathrm{mg}, 98.6 \%)$. Fraction Sh2-3 was fractioned via a silica gel (160-200mesh) column chromatography, eluting with a gradient of petroleum ether-ethyl acetate $(50: 1,40: 1$, $30: 1,20: 1,10: 1,5: 1$ ), to afford 5 fractions (Sh2-3A), fraction Sh2-3A was further purified by Sephadex LH-20 gel respectively, eluting with $\mathrm{CHCl}_{3}-\mathrm{CH}_{3} \mathrm{OH}(2: 1)$, and further purified via a silica gel (200-300 mesh) column chromatography, eluting with a gradient of $\mathrm{CHCl}_{3}-\mathrm{CH}_{3} \mathrm{OH}(40: 1,30: 1,20: 1$, $10: 1,5: 1,2: 1)$, yielding compounds $3(5 \mathrm{mg}, 96.0 \%)$ and 4 (70 mg, 97.7\%). Fraction Sh2-6 was subjected to a silica gel (160-200 mesh) column, eluting with a gradient of petroleum ether-ethyl acetate $(40: 1,30: 1,20: 1,10: 1,5: 1)$, and further purified by Sephadex LH-20 gel, eluting with $\mathrm{CHCl}_{3}-\mathrm{CH}_{3} \mathrm{OH}$ $(2: 1)$, to afford fraction (Sh2-6C). Fraction Sh2-6C was further subjected to a silica gel (200-300 mesh) column, eluting with $\mathrm{CHCl}_{3}-\mathrm{CH}_{3} \mathrm{OH}(30: 1)$ to yield compound 5 (200 mg, $98.5 \%$ ). The $\mathrm{BuOH}$ extract was fractionated via macroporous adsorption resin (AB-8) column chromatography, eluting with a gradient of increasing EtOH (0-95\%) in $\mathrm{H}_{2} \mathrm{O}$, the resulting elutes were combined into 5 fractions (Sh1-Sh5). Fraction Sh3 ( $15 \mathrm{~g})$ was chromatographed on MCI gel column, eluting with a gradient of $\mathrm{CH}_{3} \mathrm{OH}-\mathrm{H}_{2} \mathrm{O}(15,30,50,80,100 \%)$, to afford fractions (Sh3-5). Fraction Sh3-5 was subjected to preparative HPLC, eluting with $\mathrm{CH}_{3} \mathrm{OH}-\mathrm{H}_{2} \mathrm{O}$ (3\%) repeatedly, yielding compound 6 (24 mg, 96.4\%).

Cell Culture The SH-SY5Y cells (ATCC) were grown in Dulbecco's modified Eagle's medium (DMEM) supplemented with penicillin $(100 \mathrm{IU} / \mathrm{mL})$, streptomycin $(100 \mu \mathrm{g} / \mathrm{mL})$ and $10 \%$ (v/v) fetal bovine serum (FBS, Gemini, U.S.A.). Cells were maintained at $37^{\circ} \mathrm{C}$ in a saturated humidity atmosphere containing $95 \%$ air and $5 \% \mathrm{CO}_{2}$. Experiments were initiated until cells grew to $60-70 \%$ confluences. Cells were differentiated in the presence of $5 \mu \mathrm{mol} / \mathrm{L}$ ATRA (Aladdin, China) for $4 \mathrm{~d}$ in the cell medium and reducing the serum level to $1 \%$. The medium was changed every $2 \mathrm{~d}$. After four days' differentiation, the medium was replaced with new DMEM with $40 \mathrm{nmol} / \mathrm{L}$ of OA (Sigma-Aldrich, MO, U.S.A.) and 1\% FBS.

Cell Viability Assay Cell viability was evaluated by 3-(4,5-dimethylthiazol-2-yl)-2,5-diphenyltetrazolium bromide (MTT) assay. SH-SY5Y cells were exposed to compounds 1-6 $(0,0.1,1,10,50$ and $100 \mu \mathrm{mol} / \mathrm{L})$ separately for $24 \mathrm{~h}$ at $37^{\circ} \mathrm{C}$. Then $10 \mu \mathrm{L}$ of MTT $(5 \mathrm{mg} / \mathrm{mL}$ stock in phosphate buffered saline (PBS)) was added to each well (96-well plate, $200 \mu \mathrm{L}$ medium/well), and incubated for $4 \mathrm{~h}$. The insoluble blue formazan was solubilized with $100 \mu \mathrm{L}$ of dimethyl sulfoxide (DMSO), and optical density (OD) values of the mixture were measured at $490 \mathrm{~nm}$ with a microplate reader (Molecular Devices, U.S.A.). MTT assays were set not less than 4 separate samples, which were measured in triplicate.

Measurement of the Synapses Cells were observed and photoed in a phase-contrast microscope connected through a video camera to a computer running adequate image analyzer 
software (Leica Microsystems, Germany). The cell bodies and neurites present in 5 randomly selected fields were counted. The length of neurites and the diameter of cell bodies were scored manually by Image pro plus 6.0 software. The ratios between cell bodies and neurites were calculated yielding the average of neurites/bodies per neuron and expressed as the mean \pm standard error of mean (S.E.M.) value. Differences were considered to be significant when $p<0.05$.

Western Blot Assay For Western blot experiments, cells were washed twice with PBS, then lysed with RIPA buffer (50 mmol/L Tris- $\mathrm{HCl}$ ( $\mathrm{pH} 7.4), 150 \mathrm{mmol} / \mathrm{L} \mathrm{NaCl}, 1 \% \mathrm{NP}-40$, $0.1 \%$ sodium dodecyl sulfate (SDS), $100 \mathrm{mg} / \mathrm{mL}$ Phenylmethyl Sulphonyl Fluoride (PMSF)) for $20 \mathrm{~min}$, cells were harvested by scraping. Lysates were then centrifuged at $13000 \times \boldsymbol{g}$ for $10 \mathrm{~min}$ at $4^{\circ} \mathrm{C}$, and supernatants were collected for analysis. The protein concentration was measured in the supernatant using the Bicinchoninic acid (BCA) Protein Assay Kit. Protein from the treated cells was mixed with loading buffer, boiled for $5 \mathrm{~min}$. Then, the protein $(30 \mu \mathrm{g})$ was loaded into each lane of a $10 \%$ SD-polyacrylamide gel, separated by SDS-polyacrylamide gel electrophoresis (PAGE) (Miniprotean; Bio-Rad) and then transferred to Immunobilon-P polyvinylidene difluoride (PVDF) (Millipore, Bedford, MA, U.S.A.) membrane. Membranes were blocked with $5 \%$ non-fat dry milk in TBS Tris-buffered saline $(10 \mathrm{mmol} / \mathrm{L}$ Tris-base, $\mathrm{pH} 7.5,68 \mathrm{mmol} / \mathrm{L}$ $\mathrm{NaCl}$ ) containing $0.1 \%$ Tween 20 for $1 \mathrm{~h}$ at room temperature. Proteins were probed with specific antibodies at proper dilutions according to the manufacturer's instruction and incubated overnight at $4^{\circ} \mathrm{C}$. The blots were rinsed and subsequently incubated with peroxidase conjugated antibodies for $1 \mathrm{~h}$ at room temperature. Following washing, antibody binding were finally developed with the enhanced chemiluminescence Western blotting detection system. Western blot bands were visualized using a 5200 Multi Luminescent image analyzer (Tanon Science \& Technology Co., Ltd., Shanghai, China) and quantified by densitometry analysis using Image pro plus 6.0 software. The following antibodies were used at the dilutions recommended by the manufacturers: Tau-5 (Abcam, U.S.A.), p-Tau Ser262 (Abcam), $\beta$-actin (Santa Cruz Biotechnology, U.S.A.), horseradish peroxidase (HRP) Goat anti-Rabbit immunoglobulin G (IgG) Antibody and HRP Goat anti-Mouse IgG Antibody (Abgent, China).

Detection of Mitochondrial Reactive Oxygen Species Levels The mitochondria-derived superoxide accumulation was measured using MitoSOX Red (Invitrogen, U.S.A.). MitoSOX Red was dissolved in DMSO to yield a $5 \mathrm{mmol} / \mathrm{L}$ stock and subsequently diluted to a working concentration of $5 \mu \mathrm{mol} / \mathrm{L}$ in warm PBS. Briefly, after the indicated treatments, cells were incubated in this MitoSOX Red solution at $37^{\circ} \mathrm{C}$ for $30 \mathrm{~min}$ and MitoSOX Red fluorescence was then measured by flow cytometry. As a positive control, $1 \mu \mathrm{mol} / \mathrm{L}$ mitotempo were used by treating SH-SY5Y cells at $37 \mathrm{C}$ for $30 \mathrm{~min}$.

Measurement of Mitochondrial Membrane Potential $\left(\Delta \psi_{\mathrm{m}}\right)$ The fluorescent probe, JC-1 (Thermo Fisher Scientific, U.S.A.), was employed to measure the mitochondrial membrane potential $\left(\Delta \psi_{\mathrm{m}}\right)$. Briefly, after the indicated treatments, cells were incubated with JC-1 staining solution $(5 \mu \mathrm{g} / \mathrm{mL})$ for $30 \mathrm{~min}$ at $37^{\circ} \mathrm{C}$. The mitochondrial membrane potential of $\mathrm{SH}-$ SY5Y cells were calculated as the fluorescence ratio of red to green. JC-1 fluorescence was measured by flow cytometry. As a positive control, mitochondria were depolarized by treating
SH-SY5Y cells with $10 \mu \mathrm{M}$ carbonylcyanidem-chlorophenylhydrazone (CCCP) at $37^{\circ} \mathrm{C}$ for $30 \mathrm{~min}$.

Statistical Analyses Data were expressed as the mean \pm S.E.M. of cell treatments from at least three independent experiments. Statistical significance was determined with SPSS 17.0 software using the Student's $t$-test and values of $p<0.05$ as significant.

\section{RESULTS AND DISCUSSION}

There are few reports about $P$. parvifolia, including the phytochemical study and pharmacological activity study. To study the chemical constituents of this plant comprehensively, in the present study, six triterpenic acids, oleanolic acid (1), betulinic acid (2), pomolic acid (3), platanic acid (4), euscaphic acid (5) and corosolic acid (6), were isolated from the aerial parts of $P$. parvifolia, and identified by the ${ }^{1} \mathrm{H}-\mathrm{NMR}$, ${ }^{13} \mathrm{C}$-NMR spectra data and comparing with the literature reported. ${ }^{18-21)}$ The purities of these compounds were tested by HPLC. This is the first time for the isolation of the six compounds from $P$. parvifolia.

Since elevated doses of plant compounds can act as prooxidants in cell culture systems and evoke cellular injury, it is necessary to ensure that no direct cell damage is caused by concentrations within the range of the tested compounds before investigating its protective effect. ${ }^{22}$ The concentration range of these six compounds was measured by testing the cell viability of SH-SY5Y cells by MTT assay. As shown in Fig. 2, compounds 1, 3-5 showed cytotoxicity to SH-SY5Y cells when its concentration was at 50 and $100 \mu \mathrm{mol} / \mathrm{L}$ and compound 2 showed cytotoxicity to the cells when the concentration was at $10-100 \mu \mathrm{mol} / \mathrm{L}$. Furthermore, compounds 2-4 showed a concentration dependence that with their concentrations increasing, the cell viability of SH-SY5Y cells decreased in the range of tested concentrations; compound $\mathbf{6}$ showed a not that obvious trend as compounds $\mathbf{2 - 4}$, but it did not affect the viability of SH-SY5Y cells that much. Therefore, in conclusion, at the concentrations of $0.1 \mu \mathrm{mol} / \mathrm{L}$, all of these compounds had little cytotoxicity on the SH-SY5Y cells. And this can be an indication of the choice of the compounds' concentrations.

To investigate the neuroprotective activities of the six triterpenic acids from $P$. parvifolia., firstly, the SH-SY5Y cells were treated with $5 \mu \mathrm{mol} / \mathrm{L}$ ATAR for four days, after the cells were differentiated to mature neurons, then the differentiated cells were co-treated with $\mathrm{OA}(40 \mathrm{nmol} / \mathrm{L})$ and each of the compounds $(100 \mathrm{nmol} / \mathrm{L})$ for $6 \mathrm{~h}$ in DMEM with 1\% FBS. Phosphorylation tau (Ser 262 site) was assessed via Western blot analysis (Figs. 3A, B), and the lower expression of phosphorylated tau protein, the better of the neuroprotective against the OA induced neurotoxicity. The differentiated cells were used as black control, the OA treated differentiated cells as model group (OA group), and differentiated cells co-treated with $\mathrm{OA}(40 \mathrm{nmol} / \mathrm{L})$ and $\mathrm{LiCl}(10 \mathrm{mmol} / \mathrm{L})$ as positive control group ( $\mathrm{LiCl}$ group). ${ }^{23,24)}$ From the results of Western blot, it can be seen that except compound $\mathbf{1}$, the phosphorylation levels of other compounds were lower than that of $\mathrm{LiCl}$ group in different degrees, and the phosphorylation levels of all the six compounds were lower than OA group. And all of the groups were compared to OA group $(* p<0.05$ and $* * p<0.01)$. The results showed that compounds $3-\mathbf{6}$ have the better protect 


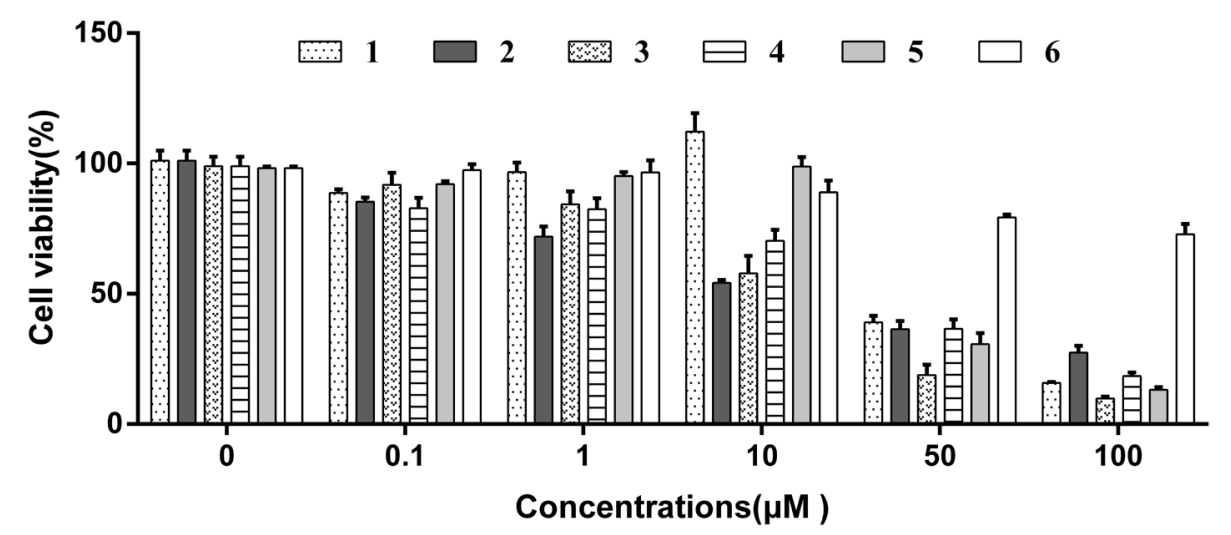

Fig. 2. MTT Cell Viability Assay of the Six Triterpenic Acids at the Concentrations of $0.1,1,10$, 50, and $100 \mu$ mol/L for $24 \mathrm{~h}$ in SH-SY5Y Cells Data are means \pm S.E.M. of 3 separate experiments performed in quadruplicate.

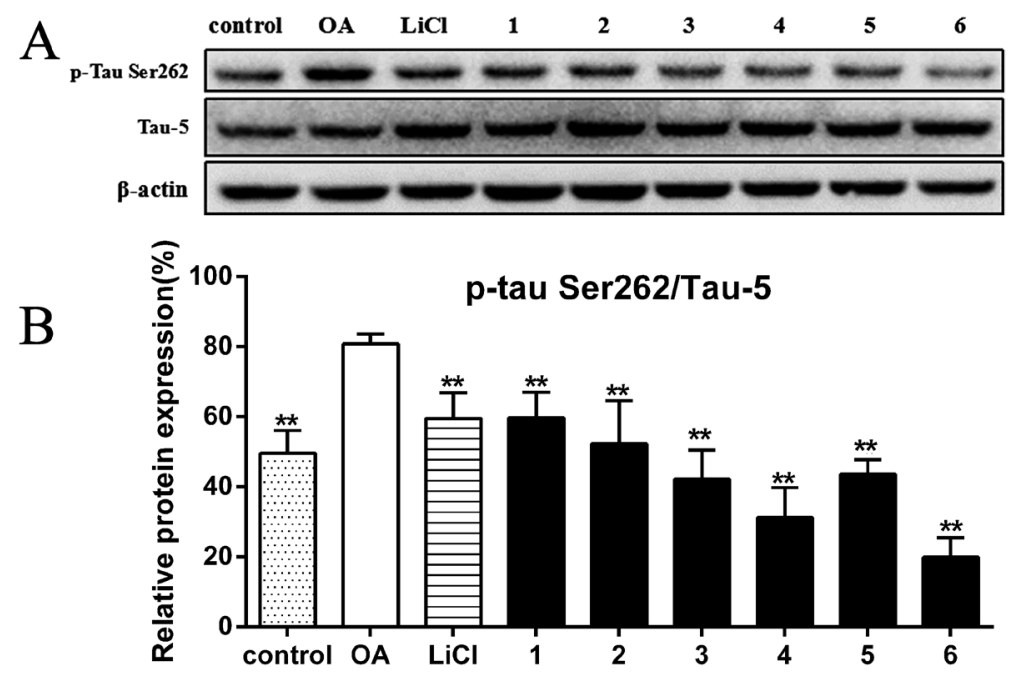

Fig. 3. Effects of Six Triterpenic Acids on the Changes Induced by OA in Phosphorylation Level of Tau

A: Western blot analysis of these triterpenic acids; B: The measurement of the phosphorylation level was conducted by the densitometric analysis of bands, all data are normalized to total tau (Tau-5). Data were presented as mean \pm S.E.M. of 3 separate experiments. $*$ means $p<0.05$ and $* * p<0.01$ compared to OA (one-way ANOVA and LSD post hoc test).

effects. Furthermore, the results can be verified by the morphology results of the cells co-treated with the six compounds and OA (Figs. 4A, B). The results suggested that the six triterpenic acids all have neuroprotective activity against OAinduced tau phosphorylation in varying degrees. Compounds 3-6 have the better effects. Above all, combined with the Western blot analysis and morphology results, compounds 3-6 gave the better neuroprotective effects in preventing the neurotoxicity induced by OA in SH-SY5Y cells. And this result made a foundation for us to further study the compounds in P. parvifolia.

Mitochondria were a major site of generation of ROS and mitochondrial dysfunction was a prominent feature in cell death, and mitochondrial dysfunction leaded to mitochondrial ROS production and $\Delta \Psi_{\mathrm{m}}$ loss. $^{25,26)}$ To investigate the mechanism of the neuroprotective effects of these compounds, the level of mitochondrial ROS and mitochondrial membrane potential $\left(\Delta \psi_{\mathrm{m}}\right)$ of these compounds in SH-SY5Y cells were tested by flow cytometry technology. The results showed that, after treated with OA, the mitochondrial ROS level was raised significantly compared with the control group, and that of the mitotempo group was reduced to $54.4 \%$ of the OA group. While, the $\Delta \psi_{\mathrm{m}}$ level of OA group was reduced to $83.3 \%$ of the control. Therefore, it can be seen from the above results that the model was successful (Figs. 5A, B). For the mitochondrial ROS level, all of the six compounds showed a lower level compared to the OA group, and compound 2 has a $47.6 \%$ level of OA group $(p<0.01)$, compounds $\mathbf{5}$ and $\mathbf{6}$ showed a 51.5 and $55.3 \%$ level of OA group, respectively $(p<0.05)$ (Fig. 5A). For the mitochondrial $\Delta \psi_{\mathrm{m}}$ level, all of the six compounds showed a higher level in comparison with the OA group, compounds $\mathbf{1}, 5$ and $\mathbf{6}$ significantly reversed the OA-induced the decrease of $\Delta \psi_{\mathrm{m}}(p<0.01)$ and compounds $\mathbf{2}-\mathbf{4}$ has a rise level compared to OA group (Fig. 5B). The above results indicated that compounds 2, 5 and $\mathbf{6}$ may protect the mitochondria from damaging. In combination of the above results of Western blot analysis and morphology, compounds $\mathbf{5}$ and $\mathbf{6}$ may play an important role in protecting SH-SY5Y cells against OA-induced injury via the protection of mitochondria dysfunction.

Increasing reports suggested an important role of mitochondrial dysfunction and oxidative stress in the pathogenesis of $\mathrm{AD}{ }^{27,28)}$ Furthermore, some data suggested that tau plays a key role in the pathogenic cascade. Tau pathology leads to reduced mitochondrial membrane potential reduced ATP levels, followed by enhanced ROS production. ${ }^{29)}$ On the other hand, mitochondrial oxidative stress also can cause hyper- 

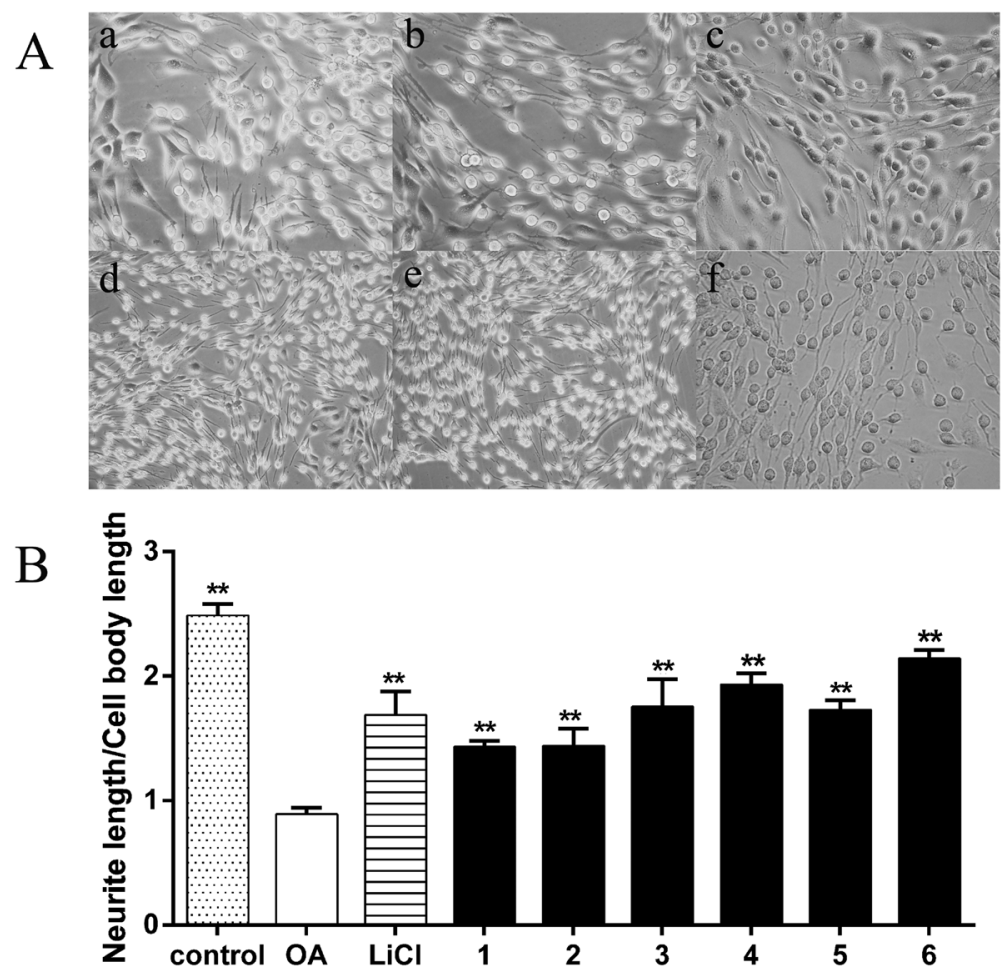

Fig. 4. Cell Morphology of the Six Triterpenic Acids Treated with OA

A: Cell morphology observed by phase contrast microscopy; B: Cell morphology results of these compounds were evaluated by the ratio of neurite length/cell body length. Data were presented as mean \pm S.E.M. of 3 separate experiments. * means $p<0.05$ and $* * p<0.01$ compared to OA (one-way ANOVA and LSD post hoc test).

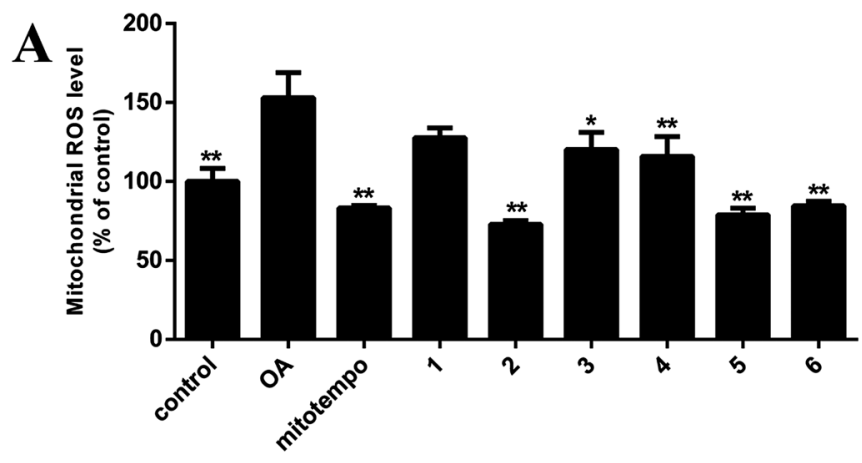

B

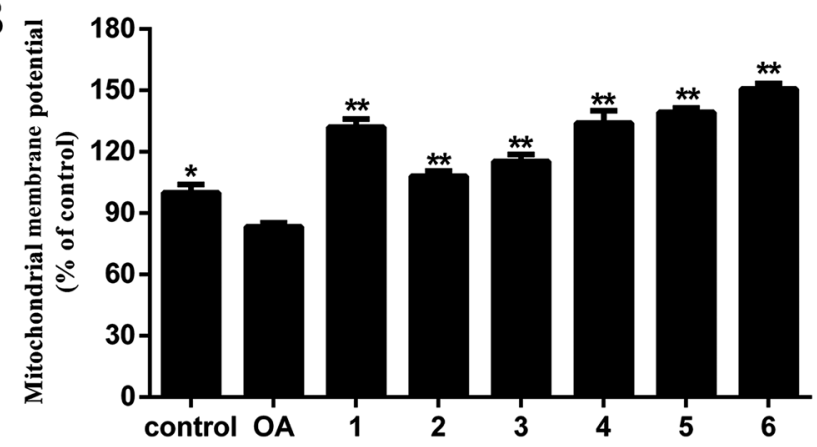

Fig. 5. Mitochondrial ROS and Mitochondrial Membrane Potential after Treated with $\mathrm{OA}$ and These Compounds

A: Mitochondrial ROS level; B: Mitochondrial membrane potential level. Data were presented as mean \pm S.E.M. of 3 separate experiments. * means $p<0.05$ and $* * p<0.01$ compared to OA (one-way ANOVA and LSD post hoc test).

phosphorylation of tau. ${ }^{30)}$ Oxidative stress increases aberrant tau phosphorylation by activation of glycogen synthase kinase 3 (GSK-3). ${ }^{31)}$ Maybe tau accumulation acts in synergy on oxidative stress and mitochondrial dysfunction, and both mi- tochondrial dysfunction and oxidative stress clearly play an important role in the pathogenesis of AD. Nevertheless, the precise mechanism of events in AD pathogenesis still remains uncertain. ${ }^{32,33)}$

Previous studies have shown that triterpenoids have the neuroprotective activities against 1-methyl-4-phenylpyridinium $\left(\mathrm{MPP}^{+}\right)$-induced and glutamate-induced neurotoxicity. ${ }^{34,35)}$ The results from the present study further suggested that triterpenoids have the neuroprotective effects. The results suggest that triterpenes from $P$. parvifolia attenuates mitochondrial dysfunction induced by OA, and such effects may play an important role in protecting SH-SY5Y cells against OA-induced cytotoxicity. These protective effects might be associated with improving mitochondrial function. These findings suggest a promising role of euscaphic acid and corosolic acid as a novel therapeutic strategy for AD. However, SH-SY5Y cells cannot totally represent the characters of primary cultured neurons, and further work needs to focus directly on primary neurons and in vivo models. Although there is no known clinical treatment that can stop or reverse the progression of the disease completely, one approach is to investigate traditional herbals as possible natural therapeutic agents. In the present investigation, we isolated six triterpenic acids from $P$. parvifolia, and tested their neuroprotective effects by an in vitro AD cell model. These findings on the compounds of $P$. parvifolia possessing neuroprotective activities may provide some ideas for the development of agents to ameliorate cellular dysfunction due to OA-induced toxicity. And these findings may give a foundation of the further study of $P$. parvifolia.

Acknowledgments This work was supported by Qinghai Provincial Science Foundation (2016-ZJ-01, 2015-SF-121), the Open Project of State Key Laboratory of Plateau Ecology and 
Agriculture, Qinghai University (2016-KF-05), Shandong Provincial Science Foundation (ZR2017MH024) and the Shuangbai Project of Yantai.

Conflict of Interest The authors declare no conflict of interest.

\section{REFERENCES}

1) Xing C, Peng Y, Chang R, Yin YL, Xie ZP. Effects of insulin-like growth factor-1 on okadaic acid-induced apoptosis in SH-SY5Y cells. Cell Biol. Int., 29, 803-808 (2005).

2) Kamat PK, Rai S, Nath C. Okadaic acid induced neurotoxicity: An emerging tool to study Alzheimer's disease pathology. Neurotoxicology, 37, 163-172 (2013).

3) Encinas M, Iglesias M, Llecha N, Comella JX. Extracellularregulated kinases and phosphatidylinositol 3-kinase are involved in brain-derived neurotrophic factor-mediated survival and neuritogenesis of the neuroblastoma cell line SH-SY5Y. J. Neurochem., 73 , 1409-1421 (1999).

4) Shipley MM, Mangold CA, Szpara ML. Differentiation of the SHSY5Y human neuroblastoma cell line. J. Vis. Exp., 108, 709-712 (2016).

5) Lei H, Zhao CY, Liu DM, Zhang Y, Li L, Wang XL, Peng Y. $\mathrm{L}-3-n$-Butylphthalide attenuates $\beta$-amyloid-induced toxicity in neuroblastoma SH-SY5Y cells through regulating mitochondrionmediated apoptosis and MAPK signaling. J. Asian Nat. Prod. Res., 16, 854-864 (2014).

6) Razmara A, Duckles SP, Krause DN, Procaccio V. Estrogen suppresses brain mitochondrial oxidative stress in female and male rats. Brain Res., 1176, 71-81 (2007).

7) Reddy PH, Beal MF. Amyloid beta, mitochondrial dysfunction and synaptic damage: implications for cognitive decline in aging and Alzheimer's disease. Trends Mol. Med., 14, 45-53 (2008).

8) Zhang Y, Li P, Li CX, Han DH, Lin M. Medicinal plants of Potentilla species. Zhongshouyi Yiyao Zazhi, 2, 60-63 (2005).

9) Chen C, Zhao XH, Zhang XW, Shao Y, Tao YD, Mei LJ. Determining the content of trace element in Potentilla Parvifolia Fisch at different altitudes. Guang Pu Xue Yu Guang Pu Fen Xi, 30, 3140-3142 (2010).

10) Qing GL, Chen SY, Ha SB, Yang DZ, Bao LE. The investigation report of Mongolian medicine plant resources of Helan mountain. Zhongguo Minzu Yiyao Zazhi, 8, 35-48 (2014).

11) Li CH, Geng SL, Fan WL, Yu TQ. Artificial acclimation of Potentilla parvifolia in Huzhu Beishan Forest Region. Qinghai Nonglin Keji, 3, 47 (2002).

12) Murata T, Selenge E, Suganuma K, Asai Y, Batkhuu J, Yoshizaki F. Chromone acyl glucosides and an ayanin glucoside from Dasiphora parvifolia. Phytochem. Lett., 6, 552-555 (2013).

13) Tomczyk M, Latté KP. Potentilla-A review of its phytochemical and pharmacological profile. J. Ethnopharmacol., 122, 184-204 (2009).

14) Son IH, Park YH, Lee SI, Yang HD, Moon HI. Neuroprotective activity of triterpenoid saponins from Platycodi radix against glutamate-induced toxicity in primary cultured rat cortical cells. Molecules, 12, 1147-1152 (2007).

15) Jamila N, Khairuddean M, Yeong KK, Osman H, Murugaiyah V. Cholinesterase inhibitory triterpenoids from the bark of Garcinia hombroniana. J. Enzyme Inhib. Med. Chem., 30, 133-139 (2015).

16) Krishnamurthy RG, Senut MC, Zemke D, Min J, Frenkel MB, Greenberg EJ, Yu SW, Ahn N, Goudreau J, Kassab M, Panickar KS, Majid A. Asiatic acid, a pentacyclic triterpene from Centella asiatica, is neuroprotective in a mouse model of focal cerebral ischemia. J. Neurosci. Res., 87, 2541-2550 (2009).

17) Yuan Z, Luan GX, Wang ZH, Hao XY, Li J, Suo YR, Li G, Wang
HL. Flavonoids from Potentilla parvifolia Fisch. and their neuroprotective effects in human neuroblastoma SH-SY5Y cells in vitro. Chem. Biodivers., 14, e1600487 (2017).

18) Ju JH, Zhou L, Lin G, Liu D, Wang LW, Yang JS. Studies on constituents of triterpene acids from Eriobot rya japonica and their anti-inflammatory and antitussive effects. Chung Kuo Yao Hsueh Tsa Chih, 38, 752-757 (2003).

19) Li WH, Li Q, Li QY, Wang XG, Fan DD. Isolation, structural elucidation and antimicrobial activity examination of five lupane-type triterpenoids from the stings of Gleditsia sinensis Lam. J. Northwest Univ. (Nat. Sci. Edit.), 38, 937-942 (2008).

20) Wang B, Li WC, Tao JS, Zhong Y, Yang H. Triterpenes isolated from traditional Chinese medicine Eupatorium lindleyanum DC. $J$. Nanchang Univ. (Nat. Sci.), 37, 250-254 (2013).

21) Niu BJ, Ma ZK, Liao ZX, Ji LJ, Sun HF. Chemical constituents from Dracocephalum heterophyllum. Chin. Tradit. Herbal Drugs, 44, 147-152 (2013).

22) Palomino OM, Gouveia NM, Ramos S, Martín MA, Goya L. Protective effect of Silybum marianum and Silibinin on endothelial cells submitted to high glucose concentration. Planta Med., 83, 97-103 (2017).

23) Zhang YJ, Xu YF, Liu YH, Yin J, Wang JZ. Nitric oxide induces tau hyperphosphorylation via glycogen synthase kinase-3 $\beta$ activation. FEBS Lett., 579, 6230-6236 (2005).

24) Lovestone S, Davis DR, Webster M, Kaech S, Brion J, Matus A, Anderton BH. Lithium reduces tau phosphorylation: Effects in living cells and in neurons at therapeutic concentrations. Biol. Psychiatry, 45, 995-1003 (1999).

25) Pan LL, Liu XH, Jia YL, Wu D, Xiong QH, Gong QH, Wang Y, Zhu YZ. A novel compound derived from danshensu inhibits apoptosis via upregulation of heme oxygenase-1 expression in SHSY5Y cells. BBA, 1830, 2861-2871 (2013).

26) Liu B, Jian Z, Li Q, Li K, Wang ZY, Liu L, Tang LZ, Yi XL, Wang $\mathrm{H}$, Li CY, Gao TW. Baicalein protects Human melanocytes from $\mathrm{H}_{2} \mathrm{O}_{2}$-induced apoptosis via inhibiting mitochondria-dependent caspase activation and the p38 MAPK pathway. Free Radic. Biol. Med., 53, 183-193 (2012).

27) Leuner K, Hauptmann S, Abdel-Kader R, Scherping I, Keil U, Strosznajder JB, Eckert A, Müller WE. Mitochondrial dysfunction: the first domino in brain aging and Alzheimer's disease? Antioxid. Redox Signal., 9, 1659-1676 (2007).

28) Mattson MP, Gleichmann M, Cheng A. Mitochondria in neuroplasticity and neurological disorders. Neuron, 60, 748-766 (2008).

29) Hauptmann S, Keil U, Scherping I, Bonert A, Eckert A, Müller WE. Mitochondrial dysfunction in sporadic and genetic Alzheimer's disease. Exp. Gerontol., 41, 668-673 (2006).

30) Melov S, Adlard PA, Morten K, Johnson F, Golden TR, Hinerfeld D, Schilling B, Mavros C, Masters CL, Volitakis I, Li QX, Laughton K, Hubbard A, Cherny RA, Gibson B, Bush AI. Mitochondrial oxidative stress causes hyperphosphorylation of tau. PLOS ONE, 2 , e536 (2007).

31) Lovell MA, Xiong S, Xie C, Davies P, Markesbery WR. Induction of hyperphosphorylated tau in primary rat cortical neuron cultures mediated by oxidative stress and glycogen synthase kinase-3. $J$. Alzheimers Dis., 6, 659-671, discussion, 673-681 (2004).

32) Müller WE, Eckert A, Kurz C, Eckert GP, Leuner K. Mitochondrial dysfunction: common final pathway in brain aging and Alzheimer's disease - therapeutic aspects. Mol. Neurobiol., 41, 159-171 (2010).

33) Lin MT, Beal MF. Mitochondrial dysfunction and oxidative stress in neurodegenerative diseases. Nature, 443, 787-795 (2006).

34) Ren YS, Li Z, Xu FQ, Li LL, Wu DL, Zhang W, Jin CS. A new triterpene from buddleja lindleyana with neuroprotective effect. Rec. Nat. Prod., 11, 356-361 (2017).

35) Moon HI, Lee JH. Neuroprotective effects of triterpene glycosides from glycine max against glutamate induced toxicity in primary cultured rat cortical cells. Int. J. Mol. Sci., 13, 9642-9648 (2012). 